\title{
Pengaruh Kesadaran Metakognitif terhadap Motivasi Belajar dan Kaitannya dengan Hasil Belajar Matematika Siswa Kelas XI SMA Negeri di Kota Pare-Pare
}

\author{
Nilam Permatasari Munir \\ Institut Agama Islam Negeri (IAIN) Palopo \\ Jl. Agatis, Balandai, Kota Palopo, Sulawesi Selatan, Indonesia \\ E-mail:nilam_permatasari@iainpalopo.ac.id
}

\begin{abstract}
The study aims to analyze the descriprition of metacognitive awareness toward learning result of mathematics directly and indirectly through learning motivation of grade XI IPA student of public senior high school in Pareparecity. The study is an ex-post facto which casuality. The populations of the study were 520 grade XI IPA students of SMAN inParepare of academic years $2013 / 2014$ with as many as 221 samples. Technique used in selecting the samples was proporsional random sampling. The instrument used for the study were (1) scale of metacognitive awareness, (2) scale of intrapersonal intelligence, (3) scale of learning motivation, (4) scale of attitude on mathematics and (5) test of mathematics learning outcomes. Data were analyzed using descriptive statistics analysis and SEM (Structural Equation Modelling) analysis. The results of the study indicate that (1) most of grade XI IPA students at SMAN in Parepare has metacognitive awareness with high category, learning motivation is in extremely high category, the learning result is in low category, (2) metacognitive awarenees directly give positif influence toward learning result of Mathematics and indirectly gives negative influence toward cognitive learning result of Mathematics through motivation learning.
\end{abstract}

Keywords: Metacognitive Awareness, Learning Motivation, dan Learning Result of Mathemaatics

\begin{abstract}
Abstrak
Penelitian ini bertujuan untuk menganalisis seberapa besar pengaruh kesadaran metakognitif terhadap hasil belajar matematika baik secara langsung maupun tidak langsung melalui motivasi belajar siswa kelas XI IPA SMA Negeri di Kota Parepare. Jenis penelitian ini adalah ex-post facto yang bersifat kausalitas. Populasi penelitian ini adalah siswa kelas XI IPA SMA Negeri di Kota Parepare tahun pelajaran 2013/2014 sebanyak 520 dengan jumlah sampel 221. Teknik penentuan sampel dilakukan dengan menggunakan proporsional random sampling. Instrumen yang digunakan dalam penelitian ini adalah (1) Skala kesadaran metakognitif, (2) Skala motivasi belajar, (3) tes hasil belajar matematika. Data dianalisis dengan statistika deskriftif dan analisis SEM (Structure Equation Modelling). Hasil penelitian menunjukkan bahwa: (1) Sebagian besar siswa Kelas XI IPA SMA Negeri di Kota Parepare memiliki kesadaran metakognitif berada dalam kategori tinggi, motivasi belajar berada dalam kategori sangat tinggi, hasil belajar berada dalam kategori rendah (2) Kesadaran metakognitif secara langsung berpengaruh positif terhadap hasil belajar matematika dan secara tidak langsung berpengaruh negatif terhadap hasil belajar kognitif matematika melalui motivasi belajar;
\end{abstract}

Kata Kunci: Kesadaran Metakognitif, Motivasi Belajar, dan Hasil Belajar Matematika 


\section{Pendahuluan}

Matematika sebagai salah satu ilmu dasar yang marupakan alat penata nalar dalam membentuk sikap dan menumbuh kembangkan kemampuan berpikir logis, sistematis serta kritis dalam diri siswa. Peranan matematika dalam mengembangkan kemampuan berpikir seseorang yang menjadikan matematika sebagai suatu sarana yang memegang peranan yang cukup besar dalam mengembangkan ilmu pengetahuan dan teknologi. Namun kenyataan yang ada begitu berbeda, hampir setiap siswa menganggap mata pelajaran matematika adalah pelajaran sulit sehingga kurangnya motivasi siswa dalam belajar matematika akhirnya berdampak pada rendahnya hasil belajar siswa dalam mata pelajaran matematika.

Berdasarkan nilai UN siswa pada tahun 2013 mengalami penurunan jika dibandingkan dengan tahun 2012. Khususnya di Sulawesi Selatan, persentasi kelulusan tahun 2012 sebesar 99,81\% turun menjadi 98,82\% ditahun 2013². Dan dari data yang diperoleh dari dinas pendidikan Kota Parepare menunjukkan bahwa, nilai rata-rata hasil UN matematika siswa SMA (nilai UN murni matematika) di Kota Parepare pada tahun ajaran 2011/2012 adalah 7,52 sedangkan pada tahun ajaran 2012/2013 nilai ratarata matematika siswa mengalami penurunan menjadi 4,26.

\section{Kerangka Teoretis}

Hasil belajar adalah kemampuan-kemampuan yang dimiliki siswa setelah ia menerima pengalaman belajarnya ${ }^{2}$. Hasil belajar yang dicapai siswa dipengaruhi oleh dua faktor utama yakni faktor internal (faktor yang datang dari diri siswa) dan faktor eksternal (faktor yang datang dari luar siswa). Seperti dikemukakan oleh Clark bahwa hasil belajar siswa di sekolah 70\% dipengaruhi oleh kemampuan siswa dan 30\% dipengaruhi oleh lingkungan ${ }^{3}$. Faktor internal yang mempengaruhi hasil belajar terbagi atas dua yaitu faktor fisiologi (kondisi fisik dan kondisi panca indera) dan faktor psikologi (bakat, minat, kecerdasan, motivasi, dan kemampuan kognitif).dan juga keterbatasan penulis dalam berbagai hal seperti biaya, waktu, dan kemampuan ${ }^{4}$. Maka penulis hanya membatasi diri dalam kajiannya, yaitu hanyalah memperhatikan faktor internal yang mempengaruhi hasil belajar seperti kesadaran metakognitif dan motivasi belajar matematika.

1 Kemendikbud, "Kementrian Pendidikan \& Kebudayaan Badan Penelitian Dan Pengembangan," 2013, http://litbang.kemendikbud.go.id.

2 Nana Sudjana, Penilaian Hasil Proses Belajar Mengajar (Bandung: PT. Remaja Rosdakarya, 2008); Mulyono Abdurrahman, Pendidikan Bagi Anak Berkesulitan Belajar (Jakarta: Rineka Cipta, 2003).

3 Ahmad Sabri, Strategi Belajar Mengajar Dan Microteaching (Jakarta: Ciputa Press, 2005). 107.

4 Ngalim Purwanto, Psikologi Pendidikan (Bandung: PT. Remaja Rosdakarya, 2007), 


\section{Pengaruh Kesadaran Metakognitif ...}

Metakognisi adalah pengetahuan dan keyakinan mengenai prosesproses kognitif seseorang, serta usaha-usaha sadarnya untuk terlibat dalam proses berprilaku dan berpikir sehingga meningkatkan proses belajar dan memorinya ${ }^{5}$. Lebih lanjut Wellman menyatakan bahwa metakognisi sebagai suatu bentuk kognisi, atau proses berpikir dua tingkat atau lebih yang melibatkan pengendalian terhadap aktivitas kognitif6. Karena itu, metakognisi dapat dikatakan sebagai berpikir seseorang tentang berpikirnya sendiri atau kognisi seseorang tentang kognisinya sendiri. Metakognitif adalah suatu kata yang berkaitan dengan apa yang dia ketahui tentang dirinya sebagai individu yang belajar dan bagaimana dia mengontrol serta menyesuaikan prilakunya7. Seseorang perlu menyadari kekurangan dan kelebihan yang dimilikinya. Metakognitif adalah suatu bentuk kemampuan untuk melihat pada diri sendiri sehingga apa yang dia lakukan dapat terkontrol secara optimal. Kesadaran metakognitif memiliki empat komponen yaitu pengetahuan kognitif, perencanaan, monitoring, dan evaluasi ${ }^{8}$.

Mc. Donald mengatakan bahwa motivasi adalah suatu perubahan energi di dalam pribadi seseorang yang ditandai dengan timbulnya afektif (perasaan) dan reaksi untuk mencapai tujuan ${ }^{9}$. Motivasi biasanya didefinisikan sebagai keadaan internal yang membangkitkan, mengarahkan, dan memperthanankan prilaku${ }^{10}$. Lebih lanjut dikatakan motivasi belajar adalah dorongan internal dan eksternal pada siswa-siswa yang sedang belajar untuk mengadakan perubahan tingkah laku pada umumnya, dengan beberapa indikator motivasi belajar sebagai berikut: (1) adanya hasrat dan keinginan berhasil, (2) adanya dorongan dan kebutuhan dalam belajar, (3) adanya harapan dan cita-cita masa depan, (4) adanya penghargaan dalam belajar, (5) adanya kegiatan yang menarik dalam belajar, dan (6) adanya lingkungan belajar yang kondusif, sehingga memungkinkan seseorang siswa dapat belajar dengan baik.

Penelitian ini bertujuan untuk mengetahui gambaran deskriptif kesadaran metakognitif, inteligensi intrapersonal, motivasi belajar dan hasil belajar matematika siswa kelas XI IPA SMA Negeri Kota Parepare serta

${ }^{5}$ Jeanne E Ormrod, Psikologi Pendidikan: Membantu Siswa Tumbuh Dan Berkembang, 6th ed., 1 (Jakarta: Erlangga, 2008), 369.

6 Usman Mulbar, "Metakognisi Siswa Dalam Menyelesaikan Masalah Matematika," 2008, http://pangkepbermutu.files.wordpress.com/2012/05/ usman-mulbar-06.doc.

7 Suherman, Strategi Pembelajaran Matematika Kontemporer (Surabaya: JICA, 2001), 95.

8 G Schraw and R.Y. Dennison, "Assesing Metacognitive Awareness, Contemporary Educational Psychology,"

1994, http://wiki.biologyscholars.org/@api/deki/files/99/\%3Dschraw1994.pdf.

${ }^{9}$ Syaiful Bahri Djamarah, Psikologi Belajar (Jakarta: Rineka Cipta, 2005).

10 Ormrod, Psikologi Pendidikan: Membantu Siswa Tumbuh Dan Berkembang, 58. 
mengetahui dan menjelaskan seberapa besarpengaruh kesadaran metakognitif dan inteligensi intrapersonal terhadap hasil belajar matematika baik secara langsung maupun tidak langsung melalui motivasi belajar pada siswa kelas XI IPA SMA Negeri Kota Parepare

\section{Metode Penelitian}

Penelitian ini termasuk penelitian ex-post facto yang bersifat kausalitas. Peneliti dalam hal ini akan menelusuri hubungan sebab akibat (kausal) dan menguji hipotesis yang telah dirumuskan sebelumnya antara lain: kesadaran metakognitif, inteligensi intrapersonal, motivasi belajar, terhadap hasil belajar kognitif matematika dan hasil belajar afektif matematika.

Populasi dalam penelitian ini adalah seluruh siswa kelas XI IPA SMA Negeri di Kota Parepare tahun pelajaran 2013/2014, sebanyak 5 sekolah yaitu SMA Negeri 1 Model Parepare, SMA Negeri 2 Parepare, SMA Negeri 3 Parepare, SMA Negeri 4 Parepare, dan SMA Negeri 5 Unggulan Parepare dengan jumlah keseluruhan siswa dari masing-masing sekolah tersebut khususnya kelas XI IPA adalah 520 siswa. Metode pengambilan sampel yang digunakan untuk memperoleh sampel acak dan dapat merepresentasikan karakteristik populasi sesuai tujuan penelitian ini adalah menggunakan teknik proporsional random sampling dengan jumlah sampel penelitian ini adalah 221.

Pengumpulan data dilakukan dengan menggunakan skala yang terdiri dari skala kesadaran metakognitif, dan skala motivasi belajar menggunakan skala Likert dengan 5 pilihan jawaban terdiri dari Sangat Sesuai (SS), Sesuai (S), Netral (N), Tidak Sesuai (TS), Sangat Tidak Sesuai (STS).

Analisis data yang digunakan dalam penelitian ini terdiri dari dua tahap.Pertama adalah analisis data untuk butir pernyataan-pernyataan dalam instrumen, kedua adalah analisis data untuk menjawab masalah penelitian. Teknik analisis data yang digunakan adalah statistik deskriptif dan inferensial. Statistik deskriptif diperlukan untuk mendeskripsikan data dari variabel-variabel penelitian yang diajukan meliputi mean, median, variansi, skewness, kurtosis, minimum, maksimum, dan analisis prosentase. Statistik inferensial dimaksudkan untuk analisis dan validasi model yang diusulkan serta pengujian hipotesis. Oleh karena itu, digunakan teknik analisis SEM dengan menggunakan paket program AMOS (Analysis of Moment Structure) IBM versi 20.0 dan SPSS IBM versi 20.0.

1. Analisis Butir Instrumen

Untuk menilai ketepatan pengukuran dari suatu butir instrument mengukur konstruk digunakan validasi butir reliabilitas konstruk. Syarat yang dipergunkan untuk melakukan analisis validitas butir dan reliabilitas konstruk adalah bahwa setiap indikator memiliki sifat unidimensional 


\section{Pengaruh Kesadaran Metakognitif ...}

terhadap konstruknya Dalam penelitian ini setiap butir pernyataan dalam instrumen dipandang sebagai indikator dari konstruknya. Untuk itu, maka statistik uji yang digunakan adalah analisis faktor konfimatori (CFA). CFA adalah analisis faktor yang digunakan untuk menguji unidimensionalitas, validitas dan reliabilitas model pengukuran konstruk yang tidak dapat diobservasi langsung 11.

2. Syarat-syarat analisis statistika

Sebelum menggunakan statistika parametrik dalam mengestimasi parameter dan pengujian hipotesis, terlebih dahulu dilakukan pemeriksaan atas asumsi yang diperlukan teknik statistik parametrik yang digunakan. Dalam hal ini digunakan analisis SEM ${ }^{12}$.

\section{Sifat-Sifat Pengukuran}

Hasil pengujian overall model fit menunjukkan bahwa nilai Chi-square $=22,211 ; \mathrm{CMIN} / \mathrm{DF}=1,851(\leq 2,00) ; \mathrm{GFI}=0,978(\geq 0,90) ; \mathrm{AGFI}=0,916$ $(\geq 0,90) ;$ RMSEA $=0,062(\leq 0,08)$. Artinya pengukuran kesadaran metakognitif yg diusulkan fit dengan data. Selanjutnya berdasarkan model final yang ditunjukkan dalam lampiran VI diperoleh hasil analisis sebagaimana dalam Tabel 4.1, menunjukkan bahwa hasil uji kebermaknaan terhadap masing-masing koefisien bobot faktor menunjukkan seluruhnya signifikan pada tingkat kesalahan 0,05 dengan nilai estimasi koefisien bobot faktor yang distandarkan semuanya lebih besar dari nilai minimal yang direkomendasikan sebesar 0,40. Hal tersebut mengandung arti bahwa masing-masing indikator memiliki validitas dan reliabilitas yang memadai dalam mengukur variabel laten kesadaran metakognitif.

Selanjutnya untuk reliabilitas konstruk, hasil estimasi menunjukkan bahwa konstruk kesadaran metakognitif $\left(\mathrm{X}_{1}\right)$ signifikan dengan nilai cronbach alpha sebesar 0,651.

Tabel 1 Hasil Analisis Validitas Konvergen dan Reliabilitas untuk Variabel Kesadaran Metakognitif

\begin{tabular}{lrrrrrrrr}
\hline \hline & & & Loading & Estimate & S.E. & C.R. & P & $\begin{array}{c}\text { Cronbach } \\
\text { Alpha }\end{array}$ \\
\hline X1.1 & $<---$ & X1 & 0,653 & 1,000 & & & & 0,651 \\
X1.2 & $<---$ & X1 & 0,432 & 0,672 & 0,145 & 4,630 & $\mathrm{p}<0,001$ & \\
X1.3 & $<---$ & X1 & 0,428 & 0,597 & 0,147 & 4,050 & $\mathrm{p}<0,001$ & \\
X1.4 & $<---$ & X1 & 0,476 & 0,711 & 0,147 & 4,825 & $\mathrm{p}<0,001$ & \\
\hline
\end{tabular}

11 Kusnendi, Model-Model Persamaan Struktural (Satu Dan Multigroup Sampel Dengan Lisrel) (Bandung: Alfabeta, 2008), 98.

12 Ibid., 46. 


\begin{tabular}{|c|c|c|c|c|c|c|c|}
\hline & & Loading & Estimate & S.E. & C.R. & $P$ & $\begin{array}{c}\text { Cronbach } \\
\text { Alpha }\end{array}$ \\
\hline X1.5 & $<---\quad X 1$ & 0,507 & 0,820 & 0,193 & 4,244 & $\mathrm{p}<0,001$ & \\
\hline $\mathrm{X} 1.7$ & $<---\quad X 1$ & 0,405 & 0,744 & 0,176 & 4,241 & $\mathrm{p}<0,001$ & \\
\hline X1.8 & $<---\quad X 1$ & 0,528 & 0,872 & 0,182 & 4,785 & $\mathrm{p}<0,001$ & \\
\hline X1.9 & $<---\quad X 1$ & 0,630 & 1,249 & 0,402 & 3,106 & 0,002 & \\
\hline $\mathrm{X} 1.14$ & $<---\quad X 1$ & 0,481 & 0,721 & 0,158 & 4,571 & $\mathrm{p}<0,001$ & \\
\hline
\end{tabular}

Dari 15 item pernyataan yang membentuk konstruk kesadaran metakognitif ada 9 item yang hasil pengukurannya dinyatakan valid (memiliki loading $>0.40$ ). Merujuk hasil pengujian model (overall model fit test) serta memperhatikan besaran koefisien bobot faktor dan reliabilitas konstruk yang diperoleh maka dapat disimpulkan bahwa model pengukuran kesadaran metakognitif dapat diterima

Hasil pengujian overall model fit menunjukkan bahwa nilai Chi-square $=8,802$; Probability $=0,117(\geq 0,05) ; \mathrm{GFI}=0,987(\geq 0,90)$; AGFI $=0,944$ $(\geq 0,90)$; RMSEA $=0,059(\leq 0,08)$. Artinya pengukuran motivasi belajar yg diusulkan fit dengan data. Selanjutnya berdasarkan model final diperoleh hasil analisis sebagaimana dalam Tabel 2, menunjukkan bahwa hasil uji kebermaknaan terhadap masing-masing koefisien bobot faktor menunjukkan seluruhnya signifikan pada tingkat kesalahan 0,05 dengan nilai estimasi koefisien bobot faktor yang distandarkan semuanya lebih besar dari nilai minimal yang direkomendasikan sebesar 0,40. Hal tersebut mengandung arti bahwa masing-masing indikator memiliki validitas dan reliabilitas yang memadai dalam mengukur variabel laten motivasi belajar.

Selanjutnya untuk reliabilitas konstruk, hasil estimasi menunjukkan bahwa konstruk motivasi belajar $\left(\mathrm{Y}_{1}\right)$ signifikan dengan nilai cronbach alpha sebesar 0,643.

Tabel 2 Hasil Analisis Validitas Konvergen dan Reliabilitas untuk Variabel Motivasi Belajar

\begin{tabular}{ccccccccc}
\hline \hline & & & Loading & Estimate & S.E. & C.R. & P & $\begin{array}{c}\text { Cronbach } \\
\text { Alpha }\end{array}$ \\
\hline Y1.1 & $<---$ & Y1 & 0,446 & 1,000 & & & & 0,643 \\
Y1.2 & $<---$ & Y1 & 0,567 & 1,108 & 0,267 & 4,158 & $\mathrm{p}<0,001$ & \\
Y1.4 & $<---$ & Y1 & 0,554 & 1,213 & 0,278 & 4,363 & $\mathrm{p}<0,001$ & \\
Y1.6 & $<---$ & Y1 & 0,473 & 1,076 & 0,262 & 4,115 & $\mathrm{p}<0,001$ & \\
Y1.10 & $<---$ & Y1 & 0,543 & 1,360 & 0,316 & 4,305 & $\mathrm{p}<0,001$ & \\
Y1.5 & $<---$ & Y1 & 0,430 & 1,189 & 0,575 & 2,070 & 0,038 & \\
\hline \hline
\end{tabular}


Dari 11 item pernyataan yang membentuk konstruk motivasi belajar, ada 6 item yang hasil pengukurannya dinyatakan valid (memiliki loading $>$ 0.40). Merujuk hasil pengujian model (overall model fit test) serta memperhatikan besaran koefisien bobot faktor dan reliabilitas konstruk yang diperoleh maka dapat disimpulkan bahwa model pengukuran motivasi belajar dapat diterima

Hasil pengujian overall model fit menunjukkan bahwa nilai Chi-square $=55,163 ; \mathrm{GFI}=0,947(\geq 0,90) ; \mathrm{RMSEA}=0,0072(\leq 0,08)$. Artinya pengukuran hasil belajar kognitif matematika yg diusulkan fit dengan data. Selanjutnya berdasarkan model final diperoleh hasil analisis sebagaimana dalam Tabel 3, menunjukkan bahwa hasil uji kebermaknaan terhadap masing-masing koefisien bobot faktor menunjukkan seluruhnya signifikan pada tingkat kesalahan 0,05 dengan nilai estimasi koefisien bobot faktor yang distandarkan semuanya lebih besar dari nilai minimal yang direkomendasikan sebesar 0,40. Hal tersebut mengandung arti bahwa masing-masing indikator memiliki validitas dan reliabilitas yang memadai dalam mengukur variabel laten hasil belajar matematika.

Selanjutnya untuk reliabilitas konstruk, hasil estimasi menunjukkan bahwa konstruk hasil belajar kognitif matematika $\left(\mathrm{Y}_{2}\right)$ signifikan dengan nilai cronbach alpha sebesar 0,995.

Tabel 3 Hasil Analisis Validitas Konvergen dan Reliabilitas untuk Variabel Hasil Belajar Kognitif Matematika

\begin{tabular}{|c|c|c|c|c|c|c|c|c|}
\hline & & & $\begin{array}{l}\text { Loa } \\
\text { ding }\end{array}$ & $\begin{array}{l}\text { Estim } \\
\text { ate }\end{array}$ & S.E. & C.R. & $\mathrm{P}$ & $\begin{array}{c}\text { Cronb } \\
\text { ach } \\
\text { Alpha }\end{array}$ \\
\hline $\mathrm{X} 2.1$ & $<--$ & HB_Kognitif & 0,758 & 1,000 & & & & 0,995 \\
\hline $\mathrm{X} 2.2$ & $<--$ & HB_Kognitif & 0,690 & 0,913 & 0,094 & 9,707 & $\mathrm{p}<0,001$ & \\
\hline $\mathrm{X} 2.4$ & $<--$ & HB_Kognitif & 0,851 & 1,115 & 0,091 & 12,251 & $\mathrm{p}<0,001$ & \\
\hline X2.5 & $<--$ & HB_Kognitif & 0,456 & 0,588 & 0,098 & 6,023 & $\mathrm{p}<0,001$ & \\
\hline $\mathrm{X} 2.7$ & $<--$ & HB_Kognitif & 0,469 & 0,546 & 0,096 & 5,698 & $\mathrm{p}<0,001$ & \\
\hline X2.8 & $<--$ & HB_Kognitif & 0,401 & 0,491 & 0,096 & 5,114 & $\mathrm{p}<0,001$ & \\
\hline $\mathrm{X} 2.10$ & $<--$ & HB_Kognitif & 0,538 & 0,590 & 0,084 & 7,044 & $\mathrm{p}<0,001$ & \\
\hline $\mathrm{X} 2.17$ & $<--$ & HB_Kognitif & 0,609 & 0,794 & 0,089 & 8,935 & $\mathrm{p}<0,001$ & \\
\hline$X 2.22$ & $<--$ & HB_Kognitif & 0,532 & 0,634 & 0,083 & 7,615 & $\mathrm{p}<0,001$ & \\
\hline $\mathrm{X} 2.23$ & $<--$ & HB_Kognitif & 0,817 & 1,071 & 0,093 & 11,563 & $\mathrm{p}<0,001$ & \\
\hline
\end{tabular}

Dari 23 item yang membentuk konstruk hasil belajar kognitif, ada 10 item yang hasil pengukurannya dinyatakan valid (memiliki loading $>0.40$ ). Merujuk hasil pengujian model (overall model fit test) serta memperhatikan besaran koefisien bobot faktor dan reliabilitas konstruk yang diperoleh maka 
dapat disimpulkan bahwa model pengukuran hasil belajar kognitif matematika dapat diterima.

Karakteristik Distribusi Skor Responden Masing-Masing Variabel

Tabel 4 Distribusi Skor Kesadaran Metakognitif Ssiswa Kelas XI IPA SMAN di Kota Parepare

\begin{tabular}{ccccc}
\hline \hline No & Skor & Frekuensi & $\begin{array}{c}\text { Persentasi } \\
(\%)\end{array}$ & Kategori \\
\hline \hline 1 & $9 \leq K M<18$ & 0 & 0,00 & Sangat Rendah \\
2 & $18 \leq K M<24$ & 1 & 5,00 & Rendah \\
3 & $24 \leq K M<30$ & 37 & 16,70 & Sedang \\
4 & $30 \leq K M<36$ & 122 & 55,20 & Tinggi \\
5 & $36 \leq K M \leq 45$ & 61 & 27,60 & Sangat Tinggi \\
\hline & Jumlah & 221 & 100 & \\
\hline Mean & Std.Deviasi & Variansi & Minimum & Maksimum \\
\hline 34,19 & 3,662 & 13,409 & 24 & 43 \\
\hline \hline
\end{tabular}

Pada Tabel 4 menunjukkan bahwa rata-rata skor kesadaran metakognitif siswa kelas XI SMA Negeri di Kota Parepare adalah 34,19 dari skor ideal 43 yang berarti kesadaran metakognitif siswa tersebut berada dalam kategori tinggi. Dalam Tabel 4.6 juga dapat diketahui bahwa 1 orang berada pada kategori rendah, 37 orang yang berada dalam kategori sedang, 122 orang berada pada kategori tinggi, dan 61 orang lainnya berada dalam kategori sangat tinggi.

Tabel 5 Distribusi Skor Motivasi Belajar Matematika Siswa Kelas XI IPA SMAN di Kota Parepare

\begin{tabular}{|c|c|c|c|c|}
\hline No & Skor & Frekuensi & $\begin{array}{c}\text { Persentasi } \\
(\%)\end{array}$ & Kategori \\
\hline 1 & $6 \leq M B<12$ & 0 & 0,0 & Sangat Rendah \\
\hline 2 & $12 \leq M B<16$ & 2 & 0,9 & Rendah \\
\hline 3 & $16 \leq M B<20$ & 25 & 11,3 & Sedang \\
\hline 4 & $20 \leq M B<24$ & 86 & 38,9 & Tinggi \\
\hline \multirow[t]{2}{*}{5} & $24 \leq M B \leq 30$ & 108 & 48,9 & Sangat Tinggi \\
\hline & Jumlah & 221 & 100 & \\
\hline Mean & Std.Deviasi & Variansi & Minimum & Maksimum \\
\hline 24,17 & 2,801 & 7,843 & 15 & 30 \\
\hline
\end{tabular}

Pada Tabel 5 menunjukkan bahwa rata-rata skor motivasi belajar matematika siswa kelas XI SMA Negeri di Kota Parepare adalah 24,17 dari skor ideal 30 yang berarti motivasi belajar siswa tersebut berada dalam kategori tinggi. 


\section{Pengaruh Kesadaran Metakognitif ...}

Dalam Tabel 5 di atas juga dapat diketahui bahwa 2 orang yang berada dalam kategori rendah, 25 orang yang berada dalam kategori sedang, 86 orang berada pada kategori tinggi, dan 108 orang lainnya berada dalam kategori sangat tinggi

Tabel 6 Distribusi Skor Tes Hasil Belajar Matematika Siswa Kelas XI IPA SMAN di Kota Parepare

\begin{tabular}{ccccc}
\hline \hline No & Skor & Frekuensi & $\begin{array}{c}\text { Persentasi } \\
(\%)\end{array}$ & Kategori \\
\hline 1 & $0 \leq H B K<40$ & 110 & 16,7 & Sangat Rendah \\
2 & $40 \leq H B K<60$ & 41 & 48,4 & Rendah \\
3 & $60 \leq H B K<75$ & 22 & 22,2 & Sedang \\
4 & $75 \leq H B K<90$ & 37 & 9,5 & Tinggi \\
5 & $90 \leq H B K \leq 100$ & 11 & 3,2 & Sangat Tinggi \\
\hline & Jumlah & 221 & 100 & \\
\hline Mean & Std.Deviasi & Variansi & Minimum & Maksimum \\
\hline 45,88 & 31,098 & 967,059 & 0 & 100 \\
\hline \hline
\end{tabular}

Pada Tabel 6 menunjukkan bahwa rata-rata skor tes hasil belajar matematika siswa kelas XI SMA Negeri di Kota Parepare adalah 45,88 dari skor ideal 100 yang berarti hasil belajar kognitif matematika siswa tersebut berada dalam kategori rendah. Dalam Tabel 6 juga dapat diketahui bahwa 110 orang yang berada dalam kategori sangat rendah, 41 orang yang berada dalam kategori rendah, 22orang berada pada kategori sedang, dan 37 orang lainnya berada dalam kategori tinggi, dan 11 orang berada dalam kategori sangat tinggi.

\section{Pengujian Hipotesis}

Hasil estimasi parameter (regression weight) disajikan dalam Tabel 4.13 berikut:

Tabel 7 Regression Weight untuk Model Tahap Akhir

\begin{tabular}{llrrrrr}
\hline \hline & & $\begin{array}{c}\text { Standar } \\
\text { Regresion } \\
\text { Weight }\end{array}$ & Estimate & S.E. & \multicolumn{1}{c}{ C.R. } & P \\
\hline Motivasi_Belajar & Kesadaran_Metakognitif & 0,470 & 0,544 & 0,171 & 3,184 & 0,001 \\
Hasil Belajar & Kesadaran_Metakognitif & 0,191 & 0,403 & 0,361 & 1,118 & 0,264 \\
Hasil Belajar & Motivasi_Belajar & $-0,312$ & $-0,570$ & 0,381 & $-1,496$ & 0,135 \\
\hline
\end{tabular}


Berdasarkan Tabel 7, maka diperoleh persamaan model struktural sebagai berikut:

$$
\widehat{Y 1}=7,016+0,191 \mathrm{X}_{1}+(-0,312) \mathrm{X}_{2} \quad ; R_{Y_{1}}^{2}=5,1 \%
$$

Keterangan:

$X_{1}, X_{2}$ berturut-turut adalah Kesadaran Metakognitif dan Motivasi Belajar Matematika

$Y_{1}$ hasil belajar matematika

1. Pengaruh langsung terhadap hasil belajar matematika $(Y)$

Hipotesis pertama yang akan diuji adalah:

$\mathrm{H}_{0}: \gamma_{21}=0$ melawan $\mathrm{H}_{1}: \gamma_{21}>0$

Dimana $H_{1}$ menyatakan bahwa ada pengaruh langsung yang positif dan signifikan dari kesadaran metakognitif $\left(\mathrm{X}_{1}\right)$ terhadap hasil belajar kognitif matematika $\left(\mathrm{Y}_{2}\right)$ pada taraf signifikansi 0,05 . Sebagaimana ditunjukkan pada Tabel 4.14, diperoleh hasil estimasi $\widehat{\gamma_{21}}=0,191$ yang positif dengan nilai $\mathrm{p}=$ $0,264>0,05$ yang tidak signifikan. Ini berarti bahwa $H_{0}$ diterima. Jadi ada pengaruh positif yang tidak signifikan kesadaran metakognitif terhadap hasil belajar matematika pada taraf signifikansi 0,05 .

2. Pengaruh tidak langsung terhadap hasil belajar kognitif matematika (Y).

Hipotesis statistik keenam yang akan diuji adalah:

$$
H_{0}: \gamma_{11} \beta_{21}=0 \text { melawan } H_{1}: \gamma_{11} \beta_{21}>0
$$

Dimana $H_{1}$ menyatakan bahwa ada pengaruh tidak langsung yang positif dan signifikan dari kesadaran metakognitif $\left(\mathrm{X}_{1}\right)$ terhadap hasil belajar kognitif matematika $\left(\mathrm{Y}_{2}\right)$ melalui motivasi belajar $\left(\mathrm{Y}_{1}\right)$ pada taraf signifikansi 0,05 . Sebagaimana ditunjukkan pada Tabel 4.18, diperoleh hasil estimasi $\widehat{\gamma_{11}} \widehat{\beta_{11}}=0,470 \times(-0,312)=-0,147$ yang negatif dengan nilaip $=0,08>0,05$ maka dapat disimpulkan bahwa indirect effect tidak signifikan pada taraf signifikansi 0,05.

Hal ini berarti bahwa $H_{0}$ diterima pada taraf signifikansi 0,05. Jadi secara tidak langsung kesadaran metakognitif berpengaruh negative terhadap hasil belajar kognitif matematika melalui motivasi belajar belajar pada taraf signifikansi 0,05 .

Berdasarkan hasil pengujian hipotesis pertama menunjukkan bahwa kesadaran metakognitif berpengaruh positif dan tidak signifikan terhadap hasil belajar kognitif matematika. Hasil penelitian ini sejalan dengan penelitian Masrura (2011) bahwa faktor-faktor psikologis yang berpengaruh tidak signifikan terhadap prestasi belajar matematika adalah kesadaran metakognisi, Susanna (2011) bahwa tidak ada pengaruh antara kesadaran metakognitif terhadap hasil belajar kognitif siswa SMA Negeri 1 Palopo, Susantini (Susanna, 2011) juga menambahkan bahwa peningkatan metakognitif selalu diiringi dengan peningkatan hasil belajar kognitif, akan 
tetapi peningkatan kesadaran metakognitif tidak selalu disertai dengan peningkatan hasil belajar siswa.

Berdasarkan hasil pengujian hipotesis keenam menunjukkan bahwa kesadaran metakognitif berpengaruh negatif dan tidak signifikan terhadap hasil belajar kognitif matematika melalui motivasi belajar. Hasil penelitian ini sejalan dengan penelitian Hytti, et all (2010) The impact of student motivation and team behavior hasil penelitiannya ditemukan bahwa motivasi intrinsik memiliki efek negatif pada hasil belajar sementara motivasi ekstrinsik memiliki satu positif. Scraw G \& Denisson (1994) mengungkapkan dalam penelitiannya yang berjudul Assesing Metacognitive Awareness, pada Contemporary Educational Psychology bahwa kesadaran metakognitif tampaknya terlepas dari kemampuan intelektual dan prestasi akademik, yang kedua adalah bahwa keterampilan peraturan seperti pemantauan mungkin independen atau bahkan berhubungan negatif dengan pengetahuan domain,yang ketiga adalah bahwa pemantauan metakognitif tampaknya independen kemudahan pemahaman. Temuan ini penting karena mereka mengungkapkan bahwa metakognisi dapat dipisahkan dari kendala kognitif lain pada pembelajaran seperti bakat dan pengetahuan domain dan tidak dapat diprediksi seluruhnya, atau bahkan dengan tingkat moderat akurasi, atas dasar mereka.

\section{Penutup}

Berdasarkan hasil penelitian dan pembahasan, maka kesimpulan dalam peneleitian ini adalah sebagai berikut: (1) secara umum siswa Kelas XI IPA SMA Negeri di Kota Parepare memiliki kesadaran metakognitif dalam kategori tinggi, motivasi belajar matematika dalam kategori sangat tinggi, dan skor rata-rata hasil belajar matematika berada dalam kategori rendah; (2) kesadaran metakognitif berpengaruh positif dan tidak signifikan terhadap hasil belajar matematika dengan besar sumbangan efektif 0,6\%; (3) kesadaran metakognitif berpengaruh negatif dan tidak signifikan terhadap hasil belajar kognitif matematika melalui motivasi belajar matematika dengan besar sumbangan efektif 1,3\%.

Adapun saran yang dapat diberikan antara lain: (1) hasil penelitian ini dapat dijadikan informasi bagi siswa tentang faktor-faktor yang berpengaruh terhadap hasil belajar matematikanya, sehingga siswa dapat mengembangkan faktor-faktor yang ada untuk memaksimalkan belajarnya; (2) informasi hasil penelitian ini semoga dapat menjadi masukan bagi guru sehingga tidak hanya menilai kemampuan akademik siswa (hasil kognitif) saja tetapi juga mampu menilai afektif siswa sehingga dapat menghasilkan siswa yang tidak hanya memiliki prestasi yang baik tetapi siswa yang berkarakter dan baik, (3) hasil penelitian ini dapat menjadi bahan informasi 
bagi penulis lain atau calon peneliti untuk menulis dan melakukan penelitian selanjutnya yang berhubungan dengan variabel pada penulisan ini demi pengembangan hasil belajar matematika pada masa yang akan datang.

\section{Daftar Pustaka}

Abdurrahman, Mulyono. Pendidikan Bagi Anak Berkesulitan Belajar. Jakarta: Rineka Cipta, 2003.

Djamarah, Syaiful Bahri. Psikologi Belajar. Jakarta: Rineka Cipta, 2005.

Kemendikbud. "Kementrian Pendidikan \& Kebudayaan Badan Penelitian Dan Pengembangan," 2013. http://litbang.kemendikbud.go.id.

Kusnendi. Model-Model Persamaan Struktural (Satu Dan Multigroup Sampel Dengan Lisrel). Bandung: Alfabeta, 2008.

Mulbar, Usman. "Metakognisi Siswa Dalam Menyelesaikan Masalah Matematika," 2008. http://pangkepbermutu.files.wordpress.com/2012/05/ usmanmulbar-06.doc.

Nana Sudjana. Penilaian Hasil Proses Belajar Mengajar. Bandung: PT. Remaja Rosdakarya, 2008.

Ormrod, Jeanne E. Psikologi Pendidikan: Membantu Siswa Tumbuh Dan Berkembang. 6th ed. 1. Jakarta: Erlangga, 2008.

Purwanto, Ngalim. Psikologi Pendidikan. Bandung: PT. Remaja Rosdakarya, 2007.

Sabri, Ahmad. Strategi Belajar Mengajar Dan Microteaching. Jakarta: Ciputa Press, 2005.

Schraw, G, and R.Y. Dennison. "Assesing Metacognitive Awareness, Contemporary Educational Psychology," 1994. http://wiki.biologyscholars.org/@api/deki/files/99/\%3Dschraw199 4.pdf.

Suherman. Strategi Pembelajaran Matematika Kontemporer. Surabaya: JICA, 2001. 